\title{
Controlling Apple Replant Disease in 'McIntosh' Apple Trees on Various Rootstock
}

\author{
Joseph F. Costante \\ Department of Plant and Soil Science, University of Vermont, \\ Burlington, VT 05405 \\ Wesley R. Autio \\ Department of Plant and Soil Science, University of Massachusetts, \\ Amherst, MA 01003

\section{Lorraine P. Berkett \\ Department of Plant and Soil Science, University of Vermont, Burlington, VT 05405}

Additional index words. Malus domestics, Pratylenchus penetrans. yield, growth, MM.111, MM.106, M.7a, M.26

Apple replant disease (ARD) adversely affects development and performance of apple trees planted in old orchard soils; it is characterized by stunted tree growth, which reduces orchard profitability (Hoestra and Oostenbrink, 1962; Mai and Parker, 1967).

The probable cause of ARD is a complex of soil-borne microorganisms, including parasitic nematodes. The lesion nematode Pratylenchus penetrans is a component of ARD in some soils. Preplant soil fumigation improves root system development, tree growth, and cropping in some orchard sites (Hoestra and Oostenbrink, 1962; Jaffee and Mali, 1979; Mai and Parker, 1970).

We examined the effects on tree performance of preplant soil fumigation, a postplant nematicide treatment, and rootstock at the Univ. of Vermont Horticultural Research Center in 1983. Results for 1983-1985 were reported by Costante et al. (1987). We now present results for the final 4 years of the experiment (1986-1989).

Trees were on a well-drained Adams loamy sand (pH 6.2) on a 20-year-old orchard site infested with $P$. penetrans and with a diagnosed replant" disease problem (Costante et al., 1987). Eighty 'Rogers Red McIntosh' trees each on semi-dwarfing MM.111, MM. 106, M.7a, or dwarfing M.26 rootstock were planted on 2 May 1984 at 2.4 x $5.5 \mathrm{~m}$ spacing, including appropriate buffer areas.

Received for publication 24 May 1990. The cost of publishing this paper was defrayed in part by the payment of page charges. Under postal regulations, this paper therefore must be hereby marked advertisement solely to indicate this fact.
The experimental split-plot treatment arrangement included main-plot soil treatments of the preplant soil fumigants Telone C-17 (74\% 1,3-dichloropropene and 16.5\% chloropicrin; Dow Chemical, Midland, Mich.) at 374 liter $\cdot \mathrm{ha}^{-1}$ and Vorlex $(80 \%$ chlorinated C3 hydrocarbons, including dichloropropenes, dichloropropane, and related chlorinated hydrocarbons and 20\% methyl isothiocynanate; NOR-AM Chemical, Wilmington, Del. ) at 281 liter $\cdot$ ha $^{-1}$, a post-plant nematicide, Nemacur 3 [ethyl 3-methyl-4(methylthio) phenyl (1-methylethyl) phosphoramidate, 35\%; Mobay Corp., Kansas City, Me. ] at 47 liters in 281 liters of water/ ha, and an untreated control replicated four times each in a randomized complete-block design and applied in 1983 (preplant) or 1984 (postulant). Subplot treatments were comprised of the four rootstock; each of the 16 subplots contained 20 trees, five per rootstock (Costante et al., 1987).

Total yield was assessed on 13 Sept. 1986 (124 days after full bloom, DAFB), 16 Sept. 1987 (128 DAFB), 17 Sept. 1988 (122 DAFB), and 20 Sept. 1989 (125 DAFB). Trunk circumference was measured at $45 \mathrm{~cm}$ above the soil surface in October each year and expressed as trunk cross-sectional area (TCSA). Yield efficiency was calculated as total tree yield $/ \mathrm{cm}^{2}$ TCSA.

Collection and analysis of soil and feederroot nematode samples each October were described by Costante et al. (1987). The number of $P$. penetrans in roots was determined by the wrist-action shaker method (Parker and Mai, 1974) and those in soil from $100 \mathrm{~cm}^{3}$ of soil by the modified Baermann pan technique (Townshend, 1963). Root discoloration (possible necrosis) was rated on the scale of $1=$ poor, $>20 \% ; 2=19 \%$ to $11 \% ; 3=10 \%$ to $5 \% ; 4=4 \%$ to $3 \%$; and $5=$ less than $3 \%$ discoloration.

During the last 4 years of the experiment, neither nematicide treatments nor rootstock significantly affected the number of lesion nematodes present in roots (ranging from 183 to $15 / \mathrm{g})$ or soil $\left(19.1\right.$ to $\left.3.0 / 100 \mathrm{~cm}^{3}\right)$. Population build-ups of $P$. penetrans a year or two after application of a chemical are not unusual because: 1) trees in chemically treated soil often grow well and provide healthy roots (food) for residual nematodes; 2) nematodes can increase due to reduced competition and parasitism from natural enemies; and 3) nematicide dissipation can enhance nematode reproduction after the initial 2 years of chemical effectiveness (Mai and Parker, 1970).

TCSA increments were significantly affected by fumigation treatments only in 1986 (range 27.6 to $34.0 \mathrm{~cm}$ ') when the values for the control $\left(5.3 \mathrm{~cm}^{2}\right)$ and for Nemacur $3(5.1$ $\mathrm{cm}^{2}$ ) differed from those for Telone C-17 $(7.3 \mathrm{~cm}$ ') and Vorlex $(6.5 \mathrm{~cm}$ '). Chemical soil treatment had no effect on leaf and soil composition, yield, or yield efficiency between 1986 and 1989 nor on cumulative values for these measurements.

During Spring 1990, the excavated root systems clearly were devoid of any serious soil-borne problems. Each rootstock was well developed for its age, thus presenting a good case that ARD was not a severe problem in this experiment.

\section{Literature Cited}

Costante, J. F., W.F. Mai, J. Aleong, and R.M. Klein. 1987. Effects of apple rootstock and nematicides on Pratylenchus penetrans populations and apple tree growth. J. Amer. Soc. Hort. Sci. 112:441-144.

Hoestra, H. and M. Oostenbrink. 1962. Nematodes in relation to plant growth. IV. Pratylenchus penefrans (Cobb) on orchard trees. Neth. J. Agr. Sci. 10:286-296.

Jaffee, B.A. and W.F. Mai. 1979. Growth reduction of apple seedlings by Pratylenchus penetrans as influenced by seedling age at inoculation. J. Nematol. 11:161-165.

Mai, W.F. and K.G. Parker. 1967. Root disease of fruit trees in New York State: 1. Populations of Pratylenchus penetrans and growth of cherry in response to soil treatment with nematicides. Plant Dis. Rptr. 51:398-401.

Mai, W.F. and K.G. Parker. 1970. Controlling nematodes increases growth and yield of apples and cherries. Proc. N.Y. State Hort. Soc. 115:207-209.

Parker, K.G. and W.F. Mai. 1974. Root diseases of fruit trees in New York State. VI. Damage caused by Pratylenchus penetrans to apple trees in the orchard growing on different rootstock. Plant Dis. Rptr. 58:1007-1011.

Townshend, J.L. 1963. A modification and evaluation of the apparatus for the Oostenbrink $\mathrm{Di}$ rect Cottonwood Filter extraction method. Nematologica 9:106-110. 